\title{
Left Ventricular Mass
}

National Cancer Institute

\section{Source}

National Cancer Institute. Left Ventricular Mass. NCI Thesaurus. Code C35462.

The left ventricular volume calculated as the difference between the epicardium delimited volume and the left ventricular chamber volume. 